\title{
Chinese and Indian Trade and Investment Links with Sub-Saharan Africa: Institutions, Capabilities and Competitive Advantage
}

\author{
Nir Kshetri \\ The University of North Carolina at Greensboro
}

Cited as: Kshetri, Nir (2013). "Chinese and Indian Trade and Investment Links with SubSaharan Africa: Institutions, Capabilities and Competitive Advantage," International Journal of Technological Learning, Innovation and Development (IJTLID), 6(1/2),161-189.

\begin{abstract}
Author's bio
Nir Kshetri is Associate Professor at The University of North Carolina-Greensboro and a research fellow at Kobe University. Nir has authored four books. He has published over fifty articles in journals such as Foreign Policy, European Journal of Marketing, Journal of International Marketing, Third World Quarterly, Journal of International Management, Communications of the ACM, IEEE Computer, IEEE Security and Privacy, IEEE Software, Electronic Markets, Small Business Economics, Thunderbird International Business Review, Telecommunications Policy, Journal of International Entrepreneurship, Electronic Commerce Research and Applications, Baltic Journal of Management, IT Professional, Journal of Health Organization and Management, and International Journal of Health Care Quality Assurance. Nir has given lectures or presented papers in Canada, China, Colombia, Croatia, Czech Republic, Denmark, Dominican Republic, Ecuador, France, Germany, Greece, India, Italy, Japan, Morocco, Nepal, New Zealand, Oman, Portugal, Romania, South Africa, South Korea, Sweden, Switzerland, Thailand, Taiwan, the Philippines, the U.K., the U.S., Tunisia and Turkey.
\end{abstract}

*** Made available courtesy of Inderscience:

http://inderscience.metapress.com/content/tiw4445553hg3512/***

\begin{abstract}
*** Reprinted with permission. No further reproduction is authorized without written permission from Inderscience. This version of the document is not the version of record. Figures and/or pictures may be missing from this format of the document. $* * *$
\end{abstract}




\title{
Chinese and Indian Trade and Investment Links with Sub- Saharan Africa: Institutions, Capabilities and Competitive Advantage
}

\begin{abstract}
Because of cultural, historical and geopolitical differences, Chinese and Indian businesses have exhibited noteworthy differences in their operations in the economies in the Sub-Saharan Africa SSA. Drawing on theories related to institutions and dynamic capabilities, we analyze the ChinaIndia differences in trades and investments in the Sub-Saharan Africa. Institutional theory helps us understand legitimacy-seeking activities of various actors. The dynamic capabilities perspectives would help understand Chinese and Indian firms' creation and exploitation of competitive advantages. Our findings suggest that behaviors of Chinese and Indian firms in Africa are driven by different contexts, processes and mechanisms. These differences are reflected in the two countries' trades and investments in terms of, inter alia, the choice of strategic direction and goal, motivations, size of investments, and focus on countries based on cultural, political and economic factors. The implications for management and public policy are discussed and directions for future research are proposed.
\end{abstract}

Keywords: China, India, Africa, institutional fit, coercive isomorphism, normative isomorphism, mimetic isomorphism, south-south trade, dynamic capabilities

\section{Introduction}

The Sub-Saharan Africa’s (SSA) economic links with China and India have strengthened remarkably. The Africa-India trade grew twenty-six fold during 1991-2008. Likewise, China is the SSA's biggest trading partner. In 2010, trades between Africa and China reached US\$115 billion (telegraph.co.uk, 2011). Multinationals from the two countries have shown significant variations in their operations in Africa. For instance, China has experienced relative difficulty in dealing with democratic countries in the continent (Michel 2008). India, on the other hand, has especially strong economic links with African economies that were colonized by the British such as Kenya and Uganda (Vines and Oruitemeka, 2008; Teslik, 2007). The divergences can be attributed to differences in cultures, political systems, and economic policies of China and India. While previous researchers have extended our understanding of China's and India's trades with Africa in terms of complementary and substitute activities (Geda and Meskel, 2008), in little research have scholars examined these links from the angles of institutions, capabilities and 
competitive advantage. In general, scholars have paid relatively little attention to trades and investments in Africa. Coster (2007) forcefully argued: "Think of Africa as a normal place. There are 15 times more analysts covering Indian companies than covering African companies, and 11 times more analysts covering Chinese companies than African companies. Can someone please switch on the light and enhance our knowledge of this place a little bit?”

China's and India’s trade and investment links with Africa have also been a key issue in the policy debates of the two countries as well as those of Western democracies. For instance, expanding exports to Africa has been a crucial component of India's new foreign trade policy (Kshetri, 2011a). Likewise, observers have noted that Chinese trade and investment in Africa tend to ignore possible environmental effects, poor governance and human rights abuses, which have led to concerns in the West (Economy, 2010; Zafar, 2007).

Drawing on theories related to institutions and dynamic capabilities, we propose a framework for analyzing major drivers of China's and India's trades and investments in Africa and examine the nature of China-India differences. We use these two theoretical frameworks because whereas a dynamic capabilities perspective would help us understand the natures of Chinese and Indian firms' processes and resources to operate in the African market (Eisenhardt and Martin, 2000), formal and informal institutions in the home and the host countries affect such capabilities (Parto, 2005).

The remainder of the paper is structured as follows: The next section provides historical perspectives, contemporary developments and fundamental concepts related to Africa's economic links with India and china. Then, we develop some propositions regarding China-India differences in economic links with Africa. Next, we present our findings and provide some discussions on important issues regarding China's and India's trades and investments in Africa. 
It is followed by a section on limitations and future research. Then the implications for management and public policy are discussed. Finally, we provide some conclusions.

\section{Africa's Economic Links with India and China: Historical Perspectives, Contemporary Developments and Fundamental Concepts}

Table 1 compares China’s and India’s trades with selected African economies. In Table 2, we have compared the two countries' trade and investment in selected dimensions. As Table 1 shows, there are striking similarities and equally striking differences in the two countries' economic links with Africa.

Indian companies are doing business in over 20 African countries (Basu, 2010). Indian multinationals such as Bharti, Reliance, Tata and Ambani have been aggressively buying large African assets (Allen, 2009). As of 2007, Tata Africa had invested US\$100 million in Africa (Noronha, 2007). Indian businesses are active in Africa in such areas as automobiles, telecommunications and education. India's Bharti Airtel and South Africa’s MTN Group have been negotiating a US\$23 billion merger deal. The Indian company NIIT has 55 centers across Africa, which has provided IT training to 150,000 students (Sterling, 2009). Indian companies’ most favored destinations in the continent have been Nigeria and South Africa (Table 1). Indian automobile companies such as Tata, Mahindras and Ashok Leyland have sold about 20,000 cars in South Africa annually (Sterling, 2009).

\section{Table 1 about here}

China, on the other hand, is active in most African countries. As of the early 2011, China had signed bilateral trade deals with 45 African countries (telegraph.co.uk, 2011). It is argued that the Chinese government and its state-owned enterprises are willing to do business “anywhere, anytime, and at any price” (Economy, 2010). The number of China’s trade partners in Africa with more than US\$1 billion in trade increased from 14 in 2007 to 20 in 2008 (Xinhua, 
2009a). By the end of 2005, over 800 Chinese state-owned companies had invested in Africa in diverse areas such as trade, manufacturing, resource exploitation, transportation and agricultural development (Lagerkvist, 2009b).

Five oil-rich countries (Angola, Equatorial Guinea, Nigeria, the Republic of Congo, and Sudan) account for $85 \%$ of Africa's exports to China (Hanson, 2008). Angola, which overtook Nigeria to become the largest oil producer in the SSA, deserves special attention (Kandell, 2010). Crude petroleum accounts for about 95\% of the Angolan exports to China. 30\% of Angola's oil exports go to China (Nesbitt, 2009). Angola provides 50\% of China's African oil imports. Likewise, Ethiopia’s trade volume with China increased from US\$150 million in 2003 (Borak, 2006) to US\$1.376 billion in 2009, which was 20 times higher than in 2000 (Newbusinessethiopia.com, 2010).

By 2008, the official Indian investment in Africa was estimated at US\$2 billion and the private sector investment at US\$5 billion (Srivastava, 2008). India invested additional US\$2 billion in Africa in 2008 (Sterling, 2009). The private sector investment in Africa is led by big multinationals such as Tata Group, Ranbaxy Laboratories and Kirloskar Brothers. These companies, however, are mainly concentrated in South Africa, Nigeria and Kenya. China had invested more than US\$8 billion in Africa by 2008 (Harvard Business Review, 2009). China committed about US\$8 billion in investments in the continent in 2009 (Sterling, 2009).

Some estimates suggest that there are about a million Chinese in the continent (Danwei, 2010). Many of them went on the continent to work in SOEs but stayed to take advantage of trade opportunities (Danwei, 2010). Likewise, Africa is home to 2 million Indians (Kripalani et al., 2008). People of Indian origin account for $68 \%$ of the population in Mauritius. Ties between 
the two countries are close. Likewise, about 30,000 Indians live in Nigeria (businessstandard.com, 2009).

\subsection{Value added activities and benefits to African economies}

Unprocessed goods such as oil, ore, metals, and agricultural products make up 86\% Africa's exports to China and India. Value-added manufactured exports, on the other hand, account for 8\% of exports to China (Broadman, 2008). Analysts argue that China's and India’s trades in Africa involve one-sided benefits to the Asian giants and lack reciprocal advantages to African economies. For instance, China allegedly buys African raw materials, does the manufacturing at home and sends finished goods such as clothing, electronics, and tools back to Africa (Baldauf, 2010). High tariff rates arguably act as a barrier for high valued-added exports from Africa to China and India. Africa’s major export products to China and India such as coffee, cocoa, and cashews face such barriers (Broadman, 2007).

\section{Table 2 about here}

\subsection{An institutional perspective}

North (1990) defines institutions as macro-level rules of the game. All economic phenomena arguably have institutional components and implications (Parto, 2005). Farazmand (1999) notes: "All organizations and institutions perform in a political or power environment through which the broad parameters are more or less defined, and any organizational action contradicting rather than enhancing, or conforming to, that environmental power structure is sanctioned by institutional means of the state, whether autonomous, dependent, mediating, or weak in dealing with powerful transnational corporations”. Institutions define the parameters for business operations and hence can help us understand complex causes and roots associated with Africa's economic links with China and India. 
Institutional pressures can be explained in terms of coercive, normative and mimetic isomorphism (DiMaggio and Powell, 1983). Coercive pressure entails threat or actual use of force by a powerful actor in order to gain compliance. Normative pressure is related to cultural and professional expectations. Mimetic pressure entails mimicking behaviors of other actors that are perceived to have a higher degree of effectiveness (Lawrence et al., 2002).

\section{The nature of coercive isomorphism in Africa: China, India and Western powers}

Coercive isomorphism is the result of pressures from exogenous resources providers (Lawrence et al., 2002). Western countries as well as China and India represent important sources of resources for many African countries. In return, Western countries have exerted coercive pressures in such areas as democracy, human rights and free trade. The World Bank, the U.S. and other Western powers have long used foreign assistance as a means to provide political reform pressures (Hinshaw, 2009). The U.S. has reportedly requested African leaders to host U.S. military bases, battle terrorism, and improve human rights situation (Giry, 2004). In general, Jane’s Intelligence Review (October 12, 2004) noted that "China is able to expand its influence in Africa partly because it is viewed with more credibility than Western states with imperialist legacies”. Commenting on Chinese construction projects in Sierra Leone, Sahr Johnny, the country's ambassador to China commented: "If a G-8 country had wanted to rebuild the stadium, for example, we'd still be holding meetings. The Chinese just come and do it. They don't start to hold meetings about environmental impact assessment, human rights, bad governance and good governance" (Economy, 2010).

China's strength has arguably stemmed from its "soft power", which includes culture, political values, foreign policies, and economic attraction needed to persuade other nations to willingly adopt the same set of goals (Nye, 2004). China is especially favored by African leaders 
who do not want to implement economic or political reforms (Thompson, 2005; Wilson 1990). German President Horst Kohler commented that many African economies favor Chinese investments because the Chinese government does not impose conditions related to democracy or human rights (cf. Lee, 2009). For instance, Gabonese ex-President Omar Bongo commented that China's cooperation comes with mutual respect and regard for diversity (Giry, 2004).

Prior researchers have noted the important role of indirect coercion mechanisms associated with soft pressures (Dolowitz and Marsh, 1996). The influence of soft pressure is mostly grounded in its "framing effect", which is associated with indirect coercive transfer with no tangible punishments rather than potential coercive power such as political reform pressures (López-Santana, 2006, Dolowitz and Marsh 1996). China has framed its approach as respect to other nations' sovereignty without being involved in the internal affairs. The soft pressures could lead to better "practical compliance” if such pressures are integrated by various linking mechanisms and involve different types of domestic actors in the implementation (Barroso, 2005; López-Santana, 2006).

While India has attempted to develop a similar program known as the India Development Initiative to promote the idea of the country as a donor, it seems to be a result of ambiguity and poor performance. An Economist article notes: “.. it is not the past which haunts Indian strategists. It is a future dominated, many fear, by competition with India's vast, commodity-hungry and increasingly Afrophile neighbor, China” (Economist, 2008). India has offered several African countries discount loans to finance Indian exports. Yashwant Sinha, India's former foreign minister, noted that Indian aid to Africa "was not a carefully thought out program” (Cahturbedi, 2004).

\section{Normative isomorphism}


Normative components introduce "a prescriptive, evaluative, and obligatory dimension into social life" (Scott 1995, p. 37). To put things in context, legitimacy conferred by African citizens and policy makers upon China and India is a function of their evaluation of these economies vis-à-vis the Western powers in terms of the prescribed behaviors on trade investment and moral obligation.

China has established normative legitimacy by expressing a strong sense of moral obligation to African welfare. In 2000, China established the pro-business China-Africa Cooperation Forum with 44 African nations, which has eased the way for free-trade and investment with the region (Leggett, 2005). China is also teaming up with supranational agencies to win further legitimacy. Under the auspices of the UN Development Program (UNDP), China-Africa Business Council was opened in 2005 and is headquartered in China. Its goal is to boost China's private sector investment and development with the continent under the South-South Cooperation (SSC) Framework (china.org, 2005). It is a joint initiative between the UNDP, the Chinese government and the private-sector China Guangcai Program. Similarly, Asia-Africa Summit, another multilateral forum, is a joint initiative with the UNDP.

China has created a sense of common membership in the developing world to win normative legitimacy and has emphasized on the need for developing nations to unite together against the industrialized West. During a 2003 speech in Ethiopia, Chinese Premier Wen Jiabao said "China is ready to coordinate its positions with African countries...with a view to safeguarding the legitimate rights and interests of developing countries" (Leggett, 2005). In a keynote address at a summit of Asian and African business leaders in Jakarta, Chinese President Hu Jintao said: "Faced with both opportunities and challenges, we Asian and African countries must seize opportunities, strengthen cooperation to cope with challenges and seek common 
development" (business.iafrica.com, 2005). In 2009, China broadened its diplomatic support for Africa at a plenary session of the UN General Assembly, during which the Chinese ambassador declared: "In the reform of the Security Council, priority should be given to the greater representation of developing countries, in particular African ones” (Xinhua, 2009b). The SouthSouth connections have thus offered an alternative source of legitimacy, which has made the Chinese much more persuasive in their efforts to secure business deals in Africa.

Among the 53 African countries, China has maintained diplomatic relations with 49 and China has an embassy and ambassador in each 48 of them (except for Somalia due to security issues). Likewise, 48 of the 49 countries (except for Comoros) have embassies in China (Shinn and Eisenman, 2008).

\section{Mimetic isomorphism}

Mimetic pressure entails mimicking behaviors of other actors that are perceived to have a higher degree of effectiveness (Lawrence et al., 2002). Mimetic isomorphism occurs in an uncertain environment when an organization models after an exemplar organization that is perceived to be successful (Dickson et al., 2004). Organizations mimic other organizations in the same industry, similar in complexity, or those "on the cutting edge" (DiMaggio and Powell, 1983). We extend this logic to consider how Africans relate to the Chinese and Indian models of development.

Some governments regard China as a model of modernization and more responsive to African needs and wants than Western partners. They perceive China’s fast-growing involvement overwhelmingly positive. China also actively promotes its development model, based on a limited market economy controlled by an authoritarian government. Evidence of Chinese influence is thus more readily apparent in authoritarian regimes. Authoritarian regimes find China's modernization model preferable to free-market and democratic reforms advocated 
by the U.S. and the European Union. The degree of mimetic isomorphism of Chinese model of development is thus high in authoritarian regimes.

On the other hand, Africans consider India's model of development as less successful and far from the cutting edge. An Economist article notes: "With a munificence that accompanies 9\% growth, India recently played host to some South African development experts, who were invited to inspect sanitation and low-cost housing. Alas, their experience--of a country where 700 million people lack indoor lavatories and half the biggest city's inhabitants live in slums--did not impress. According to one insider, the South Africans laughed all the way back to the rainbow nation” (Economist, 2008).

Consider Nigeria and Kenya, which were the only SSA countries included in the 2009 Pew Global Attitudes Survey conducted by the Washington, DC-based Pew Research Center. Both have an electoral democracy and are classified by Freedom House as "partly free" countries. The Pew survey found that $85 \%$ of Nigerians have favorable opinion of China while 79\% of Nigerians have favorable opinion of the U.S. (Pew Research Center, 2009a, b). The respective proportions for Kenya were 73\% and 90\% respectively (Pew Research Center, 2009a, b). The Kenya-Nigeria differences may be attributable to U.S. president Obama's Kenyan connection and the fact that Kenya has a higher degree of political freedom than Nigeria.

\subsection{The dynamic capabilities perspective}

The dynamic capabilities perspectives helps disentangle the contexts, mechanisms and processes associated with Chinese and Indian firms' creation and exploitation of competitive advantages in Africa. Eisenhardt and Martin (2000) define dynamic capabilities as: “The firm’s processes that use resources - specifically the process to integrate, reconfigure, gain and release resources - to match and even create market change. Dynamic capabilities thus are the organizational and strategic routines, by which firms achieve new resources configurations as markets emerge, 
collide, split, evolve, and die” (p. 1107). Firms with dynamic capabilities acquire, retain and integrate resource to develop value-creating strategies (Eisenhardt and Martin, 2000).

Firms with dynamic capabilities can "integrate, build, and reconfigure internal and external competencies to address rapidly changing environments” (Teece et al., 1997, p. 516). These capabilities enable a firm to reconfigure its resource base and adapt to changing market conditions in order to achieve a competitive advantage (Zahra and George, 2002).

\section{Chinese and Indian companies' dynamic capabilities to operate in Africa}

Chinese and Indian companies are in a position to reconfigure their resources to operate in Africa. They can easily adapt the business models used in their domestic markets (Harvard Business Review, 2009). Indian firms’ capability to deliver value for money in the domestic market has been an important source of their competitive advantage to operate in the African market (Kumar, 2008). That being said, it is also clear that Chinese firms seem to be in a better position than those from India to build dynamic capabilities to operate in Africa.

First, Chinese firms have a higher degree of dominance and power in the world economy than Indian firms. For instance, compared to India, China had almost twice as many companies in the Forbes' “Global 2000” list of the world's biggest companies in 2009 (DeCarlo, 2009, Table 3). It is argued that the Indian multinational is "in an embryonic stage” (Kumar et al., 2009). While most Chinese firms in Africa are medium-sized or large state-owned enterprises, Indian companies exhibit a higher degree of heterogeneity in terms of size (Broadman, 2008).

\section{Table 3 about here}

Second, China spends higher than India on R\&D (Table 3). More importantly, Chinese firms are developing products that are relevant to developing countries. To take one example, 
researchers at China’s Tsinghua University are testing a nanotech bone scaffold in patients. Experts say that this application of nanotechnology is especially relevant for developing countries, where the number of skeletal injuries resulting from road traffic accidents is high.

Third, Chinese firms have leaner cost structures, which is important to develop valuecreating strategies in the African context. India has not been able to compete on low wages. India is currently a leader in IT services. India's emphasis on services has been less effective in building dynamic capability (Matthias, 2006). China’s dominance in manufacturing and trade, not only with Africa but also with the industrialized countries, has been at the expense of other emerging economies such as India and Mexico (Shaw et al., 2007). Harry Broadman, a World Bank adviser on Africa, put the issue this way: "The Chinese have deep pockets. They have the ability to undercut and win every contract - and not just against India. It's the US and Europe, too" (cf. Schatz and Sappenfield, 2008).

\section{China-India Differences in Economic Links with Africa: Some Propositions}

\subsection{National-level versus firm-level strategies}

Chinese firms have an access to external competencies associated with the government's deep pockets, which has been particularly important to build dynamic capabilities to operate in Africa. While most Indian companies operating in Africa are privately owned or have a mixed privatepublic ownership, most Chinese firms are state-owned (Broadman, 2008). India’s model of private investment differs from China’s model of state-managed investments (Teslik, 2007). India's operations in Africa arguably are "driven by firm-specific considerations“ (Upadhyay, 2007). According to UBS, the state accounts for at least $70 \%$ of the Chinese economy compared to less than 7\% in India (Pei, 2006).

China is actively expanding political as well as economic ties with major emerging markets in Africa and elsewhere (China Business Forecast Report, 2011). China's state-operated 
Exim Bank is the world's third largest credit agency, which, for African economies, has become an alternative to the World Bank (Hinshaw, 2009). Beyond all that, China has provided considerable development aid, mainly in the form of low-interest loans, to African countries, which has helped Chinese firms’ operations in the continent. They include US $\$ 13$ billion to Angola, US\$9 billion to the Democratic Republic of the Congo, and US\$2.5 billion to Ethiopia (Shinn and Eisenman, 2008). Commenting on Chinese approach in Africa, Prashant Ruia, group CEO of the Indian company Essar recently put the issue this way: "We are nearly five to seven years late.....Competing with the Chinese is impossible... They are building roads, airports and projects as a grant. They are taking a 20 year investment risk — something private companies like us cannot do. We do not have the kind of backing that the Chinese have, they are present on a much larger scale too. They have had a head start and have been there for the past 10 years" (cf. Sterling, 2009). Likewise, Shashi Ruia, Essar Group chairman noted that India lacks a “national vision” (Beckett, 2010).

While India has also started providing developmental aids to some African economies, it operates at a much small scale. Indian commercial loans to Africa amounted about US\$110 million in 2003 (Cahturbedi, 2004). During the India-Africa Summit in April 2008, Indian government promised that it would provide US $\$ 500$ million in grants to African countries over the next five to six years and would double credit lines to US\$5.4 billion. In May 2011, India announced a US\$5 billion development package for Africa (Baldauf, 2011).

Due to China's mature and effective foreign policy, the effect of the state's deep entrenchment in the economy on China's trade with Africa has been more pronounced and is working towards achieving national goals. Between the mid-1950s and mid-2000s, China’s foreign aid to Africa was estimated at RMB 44.4 billion in over 900 infrastructural and social 
projects (Zhan, 2006). India has responded by increasing its aid to Africa. India also offered US $\$ 5$ billion in credit at the 2008 Indian-African summit. However, these actions have brought few commercial gains to India. For instance, India has been an African Development Bank member since 1982. Yet it has less voting weight than most other donor countries such as China, Japan, Saudi Arabia, and South Korea (Feigenbaum, 2010).

One reason behind India's failure to act in its national interest and achieve national goals concerns the underdeveloped "foreign policy software" and institutions (Markey, 2009). Feigenbaum (2010) notes: "India's foreign service is tiny; seniority often trumps other criteria for promotion in the foreign service; and think tanks and university area-studies programs are underfunded and small. Improvements in these domains will be important if India is to fashion and implement more global strategies”. Comparing China’s and India’s approach to Asian economies, Atal (2010) comments: “China's success in the Subcontinent reflects India's own foreign policy blunders. .... India has been overconfident, assuming that regional neighbors would naturally choose it over Beijing without providing them with positive incentives to do so". This observation can be extended to India's relationship with African economies.

China is arguably "playing a game of scale” in Africa (Suri \& Mahajan-Bansal, 2009). In 2008, China signed a US\$9 billion civic infrastructure agreement with the Democratic Republic of Congo (DRC) for 10 million tons of copper ore (Lee, 2010).China agreed to build 2,400 miles of road, 2,000 miles of railway, 32 hospitals, 145 health centers and two universities for the DRC (Suri \& Mahajan-Bansal, 2009). China Petroleum and Chemical (Sinopec) announced that it would acquire a 55\% stake in refinery JV in Angola for US\$2.46 billion (nytimes.com, 2010). Likewise, China National Petroleum Corp. (CNPC) has invested US\$3 billion in Sudan's Greater Nile Petroleum and owns 40\% stake (Kandell, 2010). CNPC's other ventures in Africa include a 
US\$385 million refinery in Algeria and a US\$5 billion deal to develop oil in Niger (Suri \& Mahajan-Bansal, 2009).

\section{Business relationships' embeddedment in wider institutional field}

Prior research indicates that isomorphism measures that pay attention as to how they are embedded in the "wider institutional field" (Lawrence et al., 2002) or "networks of other already legitimate institutions” (Suchman 1995) are more likely to be successful. In this regard, an important dimension of Africa-China ties is a wide range of aids, concessions, assistances and technologies provided by China to African countries. Zambian economist Dambisa Moyo was quoted as saying: "No country has had a bigger impact [than China] on the political, economic and social fabric of Africa" (Macdonald, 2010). During the second China-Africa trade summit held in Addis Ababa in 2003, China wrote off US $\$ 1.3$ billion in debt owed by 31 heavily indebted African countries. In an effort to boost trade links, China has provided 28 most underdeveloped African countries with zero tariff treatment and special preferential tariff rate for exports of about 190 products to China. These range from food, mineral product and textile, to machinery and electronics.

While China's relation with Africa in the 1960s and 1970s was rooted in political and ideological solidarity, it is becoming more economic driven. Nonetheless, continuation of activities that were originally designed to spread Chinese-style communism have helped to strengthen China's economic ties. There are about a thousand Chinese doctors working with HIV/Aids patients in Africa and over 10,000 agricultural engineers working in Africa. These factors have influenced the lens through which Africans view China.

To gather cognitive legitimacy, China is strengthening cultural ties. China International Radio, the voice of Beijing, launched a new FM station in Nairobi, Kenya, which broadcasts 19 hours a day in English, Chinese and Kiswahili. The voice of Beijing is competing with the BBC 
World Service and Voice of America. Similarly, in 2003, more than 6,000 African students received technical training in Chinese universities. China's early relations with the continent included large number of scholarships for African elites to study in China. Likewise, by 2004, China had sent 1,401 peacekeeping troops to take part in nine UN missions in Africa. Similarly, by the end of 2004, 840 Chinese peacekeepers participated in seven UN missions in Africa (African Times, 2004a). In the same vein, since 1964, China has sent over 15,000 doctors to over 47 African countries and treated approximately 180 million patients (Nye, 2004).

Official contacts between China and Africa include frequent high-level visits by the President, the Premier, and ministers. Most impressive of all, since 1991, the foreign minister's first foreign visit each year has been to Africa (Shinn and Eisenman, 2008). The above leads to the following:

Proposition 1: Indian firms' behaviors are more likely to serve to implement specific choices made by an organization and are therefore likely to follow from the firm's specific strategy. Chinese firms' programs and initiatives, on the other hand, are more focused on accomplishing national-level goals.

Corollary to Proposition 1: Chinese firms are likely to have more large-scale investments ${ }^{1}$ in Africa than Indian firms.

\subsection{Resource-seeking versus market-seeking investments}

It would also be interesting to compare China's and India's approach to market-seeking and resource-seeking investments in Africa. Resource seeking investments are made in order to establish access to basic material, input factors and natural-resource such as those in energy, metallic minerals, wood, paper and other raw materials. Market seeking investments are made to enter an existing market or establish a new market. In this regard, it is important to note that

\footnotetext{
${ }^{1}$ By large scale investments, we mean investments over $\$ 10$ million. In India, for instance, investments exceeding Rs. 500 million (about $\$ 10$ million) are considered to be large scale investments (http://www.starpackaging.biz/content/aboutus/aboutus_businessoverview.html). Likewise, in Korea, large-scale investments are those over \$10 million each (see: “Recent Trend of Foreign Direct Investment”, Korea Herald 2001. 4. 7, http://www.keb.co.kr/english/unit/com_htm/contents-3-5-87.htm)
} 
China's consumption of electricity and other types of energies is much higher than India 's (Table 3). In 2003, China surpassed Japan to become the world's second-largest oil consumer, after the U.S. According to the U.S. Energy Information Administration, China accounted for $40 \%$ of total growth in global demand for oil during 2001-2005 (Pan , 2006). China became a net importer of petroleum products since 1993 and of crude oil since 1996. The country relies on overseas producers for one-third of its supplies and the proportion is expected to reach $60 \%$ by 2020 (business.iafrica.com, 2005). At the same time, except for coal, China lacks most other types of natural resources.

Following the President Jiang Zemin’s "go out" policy in the 1990s, which encouraged the country's state-owned enterprises to go overseas to acquire natural resources, China's trade with resource-rich developing countries has increased dramatically (Economy, 2010). China has been making offshore investments in natural resources not only in Africa but also in diverse geographical locations such as Russia and Venezuela (Altman, 2009). During 2001-7, China’s trade with Southeast Asia, Latin America, and Africa grew by 600 percent (Economy, 2010). Chambishi copper mine in Zambia is one of the biggest Chinese mining operations in Africa. In 2006, China National Offshore Oil Corporation agreed to pay US\$2.3 billion for a stake in a Nigerian oil and gas field (Srivastava, 2008). In 2009, the Chinese oil company Sinopec reportedly made an offer to Ghana for oil discovery (Connors, 2009). China offers combinations of trade and aid deals, infrastructural development, as well as educational and technical training opportunities for countries that are rich in natural resources (Economy, 2010).

In sum, while both Chinese and Indian companies have gained access to African natural resources (Teslik, 2007), the level of China’s involvement has been higher in the continent. Based on above discussion, the following proposition is presented: 
Proposition 2: Compared to Indian firms, Chinese firms are more likely to engage in resourceseeking investments in Africa.

\subsection{China vs. India in authoritarian regimes}

According to Freedom House, of the 48 countries in the SSA, only 9 (combined population:

102.6 million) were "Free" in 2010 while 23 (combined population: 496.8 million) were "Partly

Free” and 16 (combined population: 235.6 million ) were "Not Free” (freedomhouse.org 2010).

Note that 11 were in the "Free" category in 2006. Freedom House referred Africa as the

"bleakest" region in terms of political rights and civil liberties in 2009. In 2009, Africa

experienced more declines in political rights and civil liberties than any other region in the

world. Freedom House's survey indicated that human rights situation worsened in 16 countries

in Africa in 2009. According to the Council on Foreign Relations, only 40\% of African

countries are electoral democracies (Kempe, 2006).

Observers note that China has gradually changed its role in Africa from a mere trade partner to more “advisory approach” (China: Country Analysis Report, 2009). Consequently China's political influence is increasing. Such a role has a special significance in authoritarian regimes. Especially, China has been able to secure political influence rapidly in countries that are avoided by Western nations because of poor governance and opaque political systems and the lack of civil liberty and political freedom (Thompson' 2005). Pilling (2010) put it best: “China’s Communist system has little obvious attraction for advanced nations, though for those poor countries wishing to prioritise modernisation over democratic niceties it arguably offers a template”. For instance, Nigeria is fighting a continuous struggle with rebels. The Nigerian government thus preferred to have a business partner that is indifferent to human rights. In 2004, the governor of Nigeria's Kaduna Province, which was involved in sectarian killings and adopted a Shariah-based criminal law, invited Chinese investors (Giry, 2004). 
India has also intensified diplomatic and economic relations (Fidler and Ganguly, 2010).

Yet researchers have argued India's efforts to utilize its cultural and political attractiveness to its advantage have been far from effective (Lagerkvist, 2009a). Moreover, Indian model of development is not attractive for most authoritarian regimes.

One way to understand China-India differences in authoritarian regimes would be to consider China's export of censorship technologies. China has provided censorship technologies (such as phone-tapping, radio-jamming and internet-monitoring equipment) to Robert Mugabe’s government in Zimbabwe. During the election campaign in 2004, a radio-jamming device located at a military base outside Zimbabwe's capital prevented independent radio stations from broadcasting. Similarly, the shortwave station, SW Radio Africa, an independent radio station based in Britain that employs exiled Zimbabwean journalists, experienced jamming problems in 2004. VOP, a shortwave station broadcasting from Madagascar, has also reported such problems. The BBC reported that Chinese intelligence officers visited Harare in 2005 to give further training in telecommunications and radio communications to Zimbabwean technicians. South Africa-based Zim Online reported that in June 2005, Mugabe announced his government’s plan to 'outlaw the dissemination through the internet of information and material it deems offensive' (Zim Online, 2005). Another ZimOnline story in 2004 reported that Harare was seeking help and equipment from China to monitor e-mails and information exchanges. There have also been reports of arrests in an internet café for sending e-mails that criticised the government.

Experts say that China has tremendous potential to become a hotbed for advanced censorship technologies and is likely to capture a substantial share of the rapidly growing global market for such technologies, which is currently supplied by Western corporations. For instance, China’s large market allows it to test a number of experimental blocking features that cannot be done in most Western 
countries. In particular, as China is already a regional internet access provider for its neighbours such as Vietnam, North Korea, Uzbekistan and Kyrgyzstan, these countries can easily be China's market for censorship know-how and technologies. In line with these arguments, the following proposition is presented:

Proposition 3: Chinese firms' advantages over Indian firms to compete effectively are likely to be higher in African countries that perform poorly on civil liberty and political rights than those that are more democratic.

\subsection{China vs. India in Commonwealth members in Africa}

Prior researchers have suggested the prevalence of kinship-based culture in the Asian business context (Yin and Choi, 2005; Tsai and Eisingerich, 2010). In this regard, it is worth noting that compared to their Chinese counterparts, Indian immigrants are more integrated into the African society. According to a 2006 survey of ethnically Indian and Chinese business owners, about $50 \%$ of the ethnic Indians had acquired African nationalities compared to only $4 \%$ ethnic Chinese (Broadman, 2008). In general, thanks to the raj legacy, India arguably is more connected into and more compatible with the established global economy (Das, 2000; Shaw et al., 2007).

A lower degree of integration of Chinese workers into the African socioeconomic structures can also be explained with the nature of Chinese nationalism. Pei distinguishes nationalism related to universalistic ideals (democracy, rule of law, free marketplace) and institutions from that based on ethnicity, religion, language, and geography. China falls in the latter category. In China, the state arguably bolsters its legitimacy through invoking a deep sense of "Chineseness" among citizens (Ong, 1997). Sautman (2001) has documented how China has adapted a body of complex scholarship to invoke a deep sense of "Chineseness": "Nowhere is this more pronounced than in China, where these disciplines [Archaeology and paleoanthropology ] provide the conceptual warp and woof of China's "racial" nationalism”. 
To move to a different issue, psychic distance from the home country or primary markets is one of the important determinants for foreign market selection (Dunning 1988). The stage model suggests that international expansion is influenced by managerial learning. Internationalization begins with low-risk, indirect exporting to "psychically close" or similar markets (Johanson and Vahlne, 1977). International activities require both general knowledge and market specific knowledge. Over time and through experience, firms increase their foreign market commitment and expand to more "psychically distant" market (Cavusgil, 1984). The network theory draws on social exchange and resource dependency and focuses on interpersonal relationships. According to this perspective, internationalization is a result of interaction and the development of a multitude of relationships. A growing body of research has demonstrated that business markets are structured as networks (Johanson and Vahlne, 1992).

One broad observation made by van de Walle (2008) shapes everything that follows: "The relationship between India and the African continent relies on private networks, linked to long-standing Indian populations in the region. The relationship between China and the region, on the other hand, is more recent and more often mediated by formal government-to-government agreements".

Traditionally, India's trade and investments in Africa were concentrated in countries that have a high proportion of Indian population, especially those colonized by the British (Teslik, 2007). For instance, today's Kenya and parts of Uganda were administered by the British out of Bombay. Indian rupees were used in these countries during 1897-1920. The rupee is still used in Seychelles and Mauritius (Vines and Oruitemeka, 2008). It is estimated that the 'Commonwealth factor' provides Indian companies a 10-15\% advantage in economic interactions in English- 
speaking countries (Shaw et al., 2007). Eighteen African countries are members of the Commonwealth of Nations.

Commonwealth African countries seem to be attractive markets for Indian firms. For instance, India’s exports to Uganda have increased in recent years. In 2004, India was the second biggest exporter to Uganda (after Kenya). In 2004, India’s exports accounted for 8.5\% of Uganda's total imports (FICCI, 2004). India’s Essar Group invested US\$100 million in Essar Telecom Kenya Holdings. As of 2009, Essar had 400,000 telecom subscribers in Kenya. Essar also has a 50\% stake in Kenya Petroleum (Suri and Mahajan-Bansal, 2009). From April-June 2007 to April-June 2008, India’s trade with East Africa grew by 82\% (Scott, 2009).

A related point is that African leaders from some Commonwealth countries have expressed their affinity with the Indians while they have been hostile to the Chinese. In 2003, during her India visit, then South African Communication Minister Ivy Matsepe Casaburri noted that India and South Africa had ties since the days of Mahatma Gandhi (Jafri, 2003). On the other hand, in 2007, the South African president warned that the continent was in a risk of being colonized by China (Pant, 2008). Michel (2008, p. 45) notes: “China seems to have difficulty maneuvering in countries more democratic than itself”. Increasing Africa-China ties have led to the closure of uncompetitive local textile mills in many African countries. Chinese businesses, however, are facing hostile reactions in more democratic countries such as South Africa (Pant, 2008). Thus, we propose that:

Proposition 4: Indian firms' advantages over Chinese firms to compete effectively are likely to be higher in the members of the Commonwealth of Nations than in non-members.

\subsection{Chinese vs. Indian firms in African countries with various levels of political risks} Prior researchers have suggested that there are high risks associated with large scale investments for the private sector. The risks are particularly high for projects involving sunk assets, which cannot be removed for use in other places or cannot be redeployed for other purposes (Rees 
1998). Normally infrastructure investments, which tend to be expensive, satisfy these criteria. In this regard, thanks to the government supports, Chinese SOEs can take risks that other multinationals avoid. Consider the Zambian copper mines. In 2009, China opened the Albidon nickel mine in Zambia, which was closed by its Australian owners (Macdonald, 2010).

Consider China's economic links with African countries that are considered to be the riskiest by the Political Risk Services’ (PRS) International Country Risk Guide (ICRG). China's most successful African energy investment has been arguably in Sudan (Hanson, 2008), which had an ICRG rank of 133 (out of 140 countries considered) in January 2010. 60\% of Sudan's oil exports go to China (Nesbitt, 2009). China's ability to manage political risks in the world's riskiest countries is apparent in its significant economic links with African economies that are considered to be riskier than North Korea (ICRG rank: 132). For instance, Equatorial Guinea (ICRG rank: 134) is a big oil supplier to China. China has a significant trade relationship with Zimbabwe (ICRG rank 138). Chinese imports from the Democratic Republic of the Congo (DRC) (ICRG rank: 139) more than quadrupled from 2004 to 2007 (N'Sakila, 2008). India’s approach to avoid political risks is summarized by Suri \& Mahajan-Bansal (2009): "Rather than run smack into Chinese competition in Africa, one tactic to tap Africa is to go to countries where China isn't as active. That's what the Essar group did. It focused on East Africa. It figured that the region was largely English speaking and had lower political risks”. It is thus proposed that:

Proposition 5: Chinese firms' advantages over Indian firms to compete effectively are likely to be higher in countries that have high political risks than those that have low political risks.

\section{Findings and Discussions}

Our findings suggest that behaviors of Chinese and Indian firms in Africa are driven by different contexts, processes and mechanisms. These differences are reflected in the two countries' trades 
and investments in Africa in terms of, inter alia, the choice of strategic direction and goal, size of investments, and focus on countries based on cultural, political and economic factors. First, due, in part, to the state's deep involvement in the economy, Chinese firms' programs and initiative in Africa are more focused on accomplishing national-level goals. A related point is that Chinese firms are more likely to be in a position to make larger scale investments in the continent. An implication of China's higher level of resource consumption and mainly state-driven economic links with Africa is that Chinese firms are more likely to engage in resource-seeking investments.

As illustrated by the arguments and examples presented above, Chinese firms' competitive advantages over Indian firms are likely to be higher in countries that perform poorly on civil liberty and political rights or those that are characterized by high political risks. Thanks to the Indians' strong cultural ties and the strong community ties, on the other hand, Indian firms' competitive advantages seem to be higher in the members of the Commonwealth of Nations. .

The different sources of legitimacy discussed above and their importance are not static. Following the analogy of social ecosystem, we can argue that international trade and investments also influence institutions. Notwithstanding their connotation of persistence, durability and stability, institutions are subject to change in evolutionary time. Zucker (1988) argues that institutions continuously undergo change due to entropy, a tendency toward disorder or disorganization. An implication of the entropy-like characteristics is that people and organizations can modify and reproduce institutions. Institutional changes take place incrementally as well as in discontinuous fashions. The pattern of international trade and investment is thus likely to change institutional structure of involved trade partners. 
The fact that China has been a big player in Africa has also made Chinese players vulnerable to attacks from various constituencies. With respect to the Africa-China business ties, not all stakeholders view China’s involvement in Africa positively. Many African manufacturers and trade unions have criticized China's approach. Some have branded China’s involvement in Africa as a new form of imperialism. South Africa's trade unions, for instance, have complained that the country's imports of cheap hi-tech products from China are ravaging domestic technology industries. In South Africa, there was a threat of a boycott of stores that carried Chinese goods in the last quarter of 2004. Some local activists want local stores to agree to a 75\%-25\% balance of locally-made to imported goods (The Economist, 2006). Similarly, Zimbabwean manufacturers and retailers have complained that Chinese imports have forced them out of business. Likewise, competition from Chinese firms forced over 10 textile factories in Lesotho to close in 2005 alone leaving 10,000 employees jobless. This phenomenon is referred as Chinese tsunami in Lesotho. A member of Lesotho's Parliament noted: ”The Chinese tsunami has created more poverty by extensive job losses" (Peta, 2005).

Some African economies are experiencing trade deficits with China, which are likely to fuel opposition to trades with China. For instance, South Africa's trade deficit with China increased from US\$24 million in 1992 to US\$400 million in 2004 (The Economist, 2006).

China’s African involvement has also been criticized by environmentalists. A July 2005 report of the International Rivers Network and Friends of the Earth accused China’s Exim Bank for funding environmental unfriendly projects such as the Merowe Dam in Sudan. Institutional changes taking place in China are also likely to alter the landscape of Africa-China trade and investment. For instance, China is undergoing a rapid privatization of its economy. Currently, China's state-owned enterprises, which are less concerned with near-term profits, 
account for a considerable share of Chinese investment in Africa (Ranneberger, 2005). Chinese private firms may not necessarily follow the same modus operandi. Moreover, as noted above, China's health diplomacy has played a critical role in winning cognitive legitimacy in Africa. Like other sectors of the Chinese economy, the medical system is also being privatized. Chinese doctors are less willing to accept postings in Africa, particularly because of a low level of current government stipend (Thompson' 2005).

Finally, there is also some movement toward democracy in Africa (Easterly, 2005), albeit very slow. A stride toward democracy and Africa's changing attitude towards issues such as humanitarian intervention (Alden, 2005) may also weaken the Africa-China business ties.

\section{Limitations and Future Research}

Several limitations of this research must be recognized in a balanced discussion of its findings.

First, because our approach was theory-building in nature and, therefore, we did not formally analyze qualitative or quantitative data on Africa's economic links with China and India. An additional limitation of this research is that we compared China's and India's trades and investments across African economies only in terms of differences in in formal and informal institutions. A further limitation is that this paper analyzed broad trade and investment ties of the two Asian giants with the SSA economies rather than those in a specific sector.

Future research is needed to address some of the above limitations. An area of future research might be to compare the two Asian giants' trades and investments in Africa in specific industries or economic sectors such as oil, outsourcing and automobile. Such study would help understand China-India differences in terms of trades and investments in Africa in relation to the important idiosyncratic features of the industry.

Second, an empirical examination of core premises of this paper would provide a deeper understanding of the two Asian giants' trade and investment links with the SSA. It would shed 
light into the contexts and mechanisms associated with institutions, capabilities and competitive advantages of Indian and Chinese firms to operate in Africa.

Finally, future research might also explore the generalizability of the above findings regarding China's and India's trades and investments to the contexts other economies. For instance, scholars need to examine if observations regarding China's higher relative success in failed states and authoritarian regimes and India's higher relative success in democratic economies are also valid in non- African developing economies.

\section{Implications for Management and Public Policy}

The preceding discussion has important managerial and policy implications:

Implication 1: The China, India and South Africa (CISA) framework

It is important to analyze China's and India's trades and investments in Africa vis-à-vis that of South Africa. Shaw et al. (2007) refer China, India and South Africa (CISA) as “"emerging economies’ aspiring towards the top tier of the global architecture” (p. 1256) and argue that CSIA will shape the policy and economic landscapes of sub-Saharan Africa in an important way. According to the UN Conference on Trade and Development's (UNCTAD), World Investment Report 2006, over 50\% of all FDI inflows in Botswana, the Democratic Republic of the Congo, Lesotho, Malawi and Swaziland came from South Africa. In this regard, it is important to note that institutions in South Africa are more similar to India than to those in China. The institutional similarity is likely to put South African companies in more direct competition with the Indian than with the Chinese.

Implication 2: The state's involvement in African economies

In most African countries, the government's relatively stronger position and control over strategic national resources have facilitated China’s access to such resources. Virtually all African countries are characterized by mixed economies. As is the case of many developing 
countries, private and public firms function side by side. In some countries, the nationalization process is still going on. For instance, in 2004, Zimbabwe's President Mugabe announced his government's plan to demand half-ownership of all privately owned mines in the country in order to stay in control of its natural resources (African Times, 2004b).

In Africa, the commercial class and the national elite have a high degree of complementary characteristics. For instance, African commercial class lacks financial and managerial ability to run "high markets" such as a copper mining company or an automobile assembly plants (Wilson 1990). State elite, on the other hand, see professional and personal rewards in nationalizing such markets. Government purchases account for a significant proportion of imports in developing countries. For instance, in all developing countries, the government is the single biggest user of technology products (Nidumolu et al., 1996). In Ethiopia, government purchases account for $40 \%$ of total imports, with loans by international financial institutions such as the World Bank and the African Development Bank. China's influence on many African governments has thus helped trigger China's exports to Africa. Implication 3: Shift towards democracy and economic freedom There has been a gradual shift towards political and economic freedom in some African countries. For instance, Ethiopia recently moved from one-party to multi-party system. The above discussion indicates that such a shift may benefit India. Indian managers tend to be more effective than Chinese in interacting and communicating with African local managers. Sterling (2009) observed: “Indian managers talk to local African managers in ways the Chinese never do". 


\section{Implication 4: Utilizing the continent's labor force}

Chinese and Indian companies have mainly concentrated on accessing the natural resources and markets in the continent. There is, however, a potential to expand their operations to utilize the continent's labor force to serve international markets, especially the European ones. For instance, Indian offshoring companies can utilize the continents’ English, French and Portuguese speaking populations to provide call center services to Europeans. Likewise, Chinese firms can use Africa's geographical position as proximity to Europe to establish factories in the continent and sell products to the European market.

Implication 5: Importance of forward and backward linkages

African economies are in an urgent need to move to a higher gear to benefit from foreign trades and investments. For instance, there are reports that the garment manufacturing industry in many parts of Africa is shallow. That is, this industry has few linkages to the domestic economies. In some African economies such as Namibia and Lesotho, even skilled direct employees for this industry are foreigners (Rasiah and Ofreneo, 2009). The host African countries can increase benefits associated with trades and investments from China and India by creating efficient channels for forward and backward linkages, labor mobility and stimulation of knowledge and technology transfer to local firms (Markusen and Venables, 1999).

\section{Conclusion}

By integrating theories related to institutions and dynamic capabilities, we have taken a significant step toward a greater understanding of the complexity involved in the South-South trade. This article has shed light on how formal and informal institutions in the home and the host countries affect the capabilities of firms based in China and India to operate in Africa. Since most studies on South-South trades have focused on intra- and inter-regional trades among Asian 
and Latin American economies, this paper has contributed to filling an important void on such trades involving Africa.

China is a bigger exogenous resources provider than India, which has helped it to exert an effective isomorphic pressure. In this regard, the soft power has been an important component of China's coercive diplomacy. China's expression of a strong sense of moral obligation to African welfare has helped it to establish normative legitimacy. China’s model of modernization has been exemplary, especially for authoritarian regimes in the continent, which has led to a higher degree of mimetic pressure. Likewise, Chinese firms’ higher degree of dominance and power in the world economy, development of products that are relevant to the developing world and access to resources have helped them build dynamic capability. While Indians living in Africa are a major source of India's competitive advantage over China, the Indian Diaspora networks have not been used effectively.

Chinese firms' better institutional fit in some African economies and the possession of dynamic capability have allowed them to expand across wider geographic markets and product categories. China has created real business values and economic benefits, which have outweighed the values of India's historical and cultural ties. China's relative advantage compared to India is, however, lower in Commonwealth English-speaking countries in Africa. 


\section{References}

African Times. (2004a) Africa's Trade Ties with China and Their Challenges. December,15, 31, 11.African Times. (2004b) Zimbabwe, September 15 - September 30, Vol. 17 No. 10, pp. 1. afriqueavenir.org (2010). 'China, Nigeria bilateral trade hit \$6 billion’, June 17, 2010 http://www.afriqueavenir.org/en/2010/06/17/china-nigeria-bilateral-trade-hit-6-billion/ (Accessed 26 October, 2010).

Alden, C. (2005) China in Africa. Survival, Vol.147, pp.18.

Allen, C. (2009) 'Private equity targets Africa', Global Investor, Vol. 221, pp. 21-22

Altman, R. C. (2009) 'Globalization in Retreat', Foreign Affairs, Vol. 88 No. 4, pp. 2-7.

Atal, M. R., (2010) 'Time to be a better neighbor, India. If you don't, China will', Christian Science Monitor, 11/9/2010

Baldauf, S. (2010) South Africa seeks value-added China investment.3 September, Available at:http://www.csmonitor.com/World/Africa/2010/0903/South-Africa-seeks-value-addedChina-investment

Baldauf, S. (2011) India boosts bid to rival China in Africa, 25 May, Available at: http://www.csmonitor.com/World/Africa/Africa-Monitor/2011/0525/India-boosts-bid-torival-China-in-Africa

Barroso, J. M. (2005) Working Together for Growth and Jobs: A New Start to the Lisbon Strategy, COM, 24, Brussels.

Basu, I. (2010) India Inc woos Africa. Available at: http://www.atimes.com/atimes/South_Asia/India-Inc-woos-Africa.html. (Accessed 20 August, 2010).

Beckett, Paul. (2010) India vs. China, Courtesy Shashi Ruia,19 November, Available at:http://blogs.wsj.com/indiarealtime/2010/11/19/india-vs-china-courtesy-shashi-ruia/

Borak, D. (2006) 'Analysis: China's Africa expansion’, UPI, 17 January.

Broadman, H. G. (2007) Africa's Silk Road: China and India's New Economic Frontier. The International Bank for Reconstruction and Development / The World Bank Washington DC

Broadman, H. G. (2008) 'China and India Go to Africa', Foreign Affairs, Vol. 87 No.2, pp95109.

Broadman, H. G. (2011) The backstory of China and India's growing investment and trade with Africa: Separating the wheat from the chaff, Columbia FDI Perspectives, The Vale Columbia Center on Sustainable International Investment, No. 34,17 February, Available at:http://www.vcc.columbia.edu/content/backstory-china-and-india-s-growing-investmentand-trade-africa-separating-wheat-chaff

business.iafrica.com. (2005) China vows to tie up with Asia, Africa. Available at: http://business.iafrica.com/news/434784.htm.(Accessed 26 October, 2009).

business-standard.com. (2009) India-Nigeria Business Forum to boost trade and investment. Available at:http://www.business-standard.com/india/news/india-nigeria-business-forum-toboost-tradeinvestment/62966/on. (Accessed 26 October, 2009)

Cahturbedi, S. (2004) India's Double Standard on International Aid as Donor and Receiver. Available at: http://www.indiadaily.com/editorial/09-27b-04.asp.(Accessed 26 October , 2009)

China Business Forecast Report, (2011) Chapter 1: Political Outlook. 1st Quarter, pp.9-14 
China Economic Review. (2006) Wen calls on Congo. Available at:http://www.chinaeconomicreview.com/dailybriefing/2006_06_20/Wen_calls_on_Congo.ht ml.(Accessed 26 October, 2009).

china.org. (2005) Business Council to Promote Sino-African Ties. Available at:http://www.china.org.cn/english/2005/Mar/123206.htm.(Accessed 26 October, 2009).

China: Country Analysis Report. (2009) China Country Profile, 2009, pp.1-93.

chinadaily.com. (2009) China signs \$260m airport deal with Mauritius. Available at:http://www2.chinadaily.com.cn/china/2009-02/17/content_7485582.htm.(Accessed 26 October, 2009).

Connors, W. (2009) Update: Sinopec Makes Offer for Ghana Oil Stake - Source. Available at:http://online.wsj.com/article/BT-CO-20091026-711678.html.(Accessed 26 October, 2009)

Coster, H. (2007) \$5 Million Carrot. Forbes Asia, Vol.3, pp. 18.

Danwei. (2010). Chinese entrepreneurs in Africa, land of a billion customers. Available at:http://www.danwei.org/china_and_africa/independent_chinese_entreprene.php. (Accessed 20 August, 2010)

Das, G. (2000). India Unbound: From Independence to the Global Information Age. Penguin, New Delhi.

DeCarlo, S. (2009). The World's Biggest Companies. Available at:http://www.forbes.com/lists/2009/18/global-09_The-Global-2000_Rank.html.(Accessed 26 October, 2009)

Department of Commerce. (2005). India to Boost Trade with Congo Commerce Minister Of Congo Meets Kamal Nath. Available at:http://commerce.nic.in/pressrelease/pressrelease_detail.asp?id=1025.(Accessed 26 October, 2009)

Dickson, M., BeShers, R., and Gupta, V. (2004). 'The impact of societal culture and industry on organizational culture: Theoretical explanations’. In Robert J. House, Paul J. Hanges, Mansour Javidan, Peter W. Dorfman, and Vipin Gupta (eds). Culture, leadership, and organizations : the GLOBE study of 62 societies. Sage Publications, Thousand Oaks, Calif.

DiMaggio, P. J., and Powell, W. W. (1983) 'The iron cage revisited: institutional isomorphism and collective rationality in organizational fields', American Sociological Review, Vol.48, pp. 147-60.

Dolowitz, D., and Marsh, D. (1996) 'Who learns what from whom: a review of the policy transfer literature', Political Studies, XLIV: pp. 343-57.

Dunning, J. (1988) Explaining International Production. Unwin Hyman, London.

Easterly, W. (2005). 'What Did Structural Adjustment Adjust? The Association of Policies and Growth with Repeated IMF and World Bank Adjustment Loans,". Journal of Development Economics Vol. 76: PP. 1-22.

Economist. (2008) When trade winds smell sweet. Vol. 387 No. 8575, pp. 67-68.

Economy, Elizabeth C. (2010) The Game Changer.. Foreign Affairs, Vol. 89 No. 6, pp.142-152

Eisenhardt, K. M., and Martin, J. A. (2000) ‘Dynamic capabilities: what are they?’, Strategic Management Journal, 21, 10/11, pp.1105-1121.

Embassy of India, Khartoum. (2009) India And Sudan Partners In Development. Available at: http://www.indembsdn.com/eng/india_sdn_partners.html. (Accessed 26 October, 2009)

Farazmand, A. (1999) 'The elite question: Toward a normative elite theory of organization', Administration \& Society, July, Vol. 31 No. 3, pp. 321-359. 
Feigenbaum, E. A. (2010). ' India's Rise, America's Interest’, Foreign Affairs, Vol.89 No.2,pp. 76-91.

FICCI. (2004) India-Uganda Economic and Commercial Relations. Available at:http://www.ficci.com/international/countries/uganda/uganda-commercialrelations.htm. (Accessed 26 October, 2009).

Fidler, D. P., and Ganguly, S. (2010) 'India and Eastphalia’ Indiana Journal of Global Legal Studies, Vol. 17 No. 1, pp.147-164.

financialnigeria.com. (2008). China, Nigeria Trade Relations Hit \$4.3 billion in 2007. Available at:http://www.financialnigeria.com/NEWS/news_item_detail_archive.aspx?item=3002. (Accessed 26 October, 2009)

fmprc.gov.cn. (2004). Chinese vice president calls for "win-win" China-Africa cooperation. Available at: http://www.fmprc.gov.cn/ce/ceza/eng/zghfz/zngx/t165296.htm. (Accessed 26 October, 2009)

Foxnews.com. (2007). Sudan Tops Agenda As Chinese President Prepares For Africa Tour. Available at:http://origin.foxnews.com/story/0,2933,248119,00.html.(Accessed 26 October, 2009)

Freedom House. (2008). Map of Freedom in the World, 2008 Edition. Available at:http://www.freedomhouse.org/template.cfm?page=363\&year=2008\&country=7461. (Accessed 26 October, 2009).

Freedomhouse.org (2010). Map of Freedom: Sub-Saharan Africa. Available at:http://www.freedomhouse.org/uploads/fiw10/FIW_2010_Map_Africa.pdf.(Accessed 26 October, 2009).

Geda, A., and Meskel, A. G. (2008) 'China and India's Growth Surge: Is it a curse or blessing for Africa? The Case of Manufactured Exports’. African Development Review, Sep2008, Vol.20 No.2, pp.247-272.

Giry, S. (2004) China's Africa Strategy: Out of Beijing. The New Republic. Available at: http://www.tnr.com/doc.mhtml?i=20041115\&s=giry111504. (Accessed 26 October, 2009)

globalinsight.com. (2008) India-Africa Relations Re-Energised in First Forum Summit. Available at: http://www.globalinsight.com/SDA/SDADetail12153.htm. (Accessed 26 October, 2009)

Hanson, S. (2008) China, Africa, and Oil June 6. Available at:http://www.cfr.org/publication/9557/china_africa_and_oil.html. (Accessed 20 August, 2009)

Harvard Business Review. (2009) The New Frontiers, Vol 87 No. 7, pp.130-137.

Hinshaw, D. (2009) 'President Obama Arrives in Ghana this Weekend, But China's Booming Africa Presence May Mean That He'll Have Less Leverage To Advance US Interests Than His Predecessors'. The Christian Science Monitor. Available at:http://www.csmonitor.com/2009/0710/p90s01-woaf.html.(Accessed 26 October, 2009).

Jafri, S. A. (2003) South Africa invites Indian IT, telecom firms. Available at:http://www.rediff.com/money/2003/apr/26safrica.htm?zcc=rl. (Accessed 26 October, 2009).

Johanson, J., and Vahlne, J. (1977) 'The Internationalization Process of a Firm - A Model of Knowledge Development and Increasing Foreign Market Commitments’, Journal of International Business Studies, Spring/summer Vol. 8, pp. 23-32. 
Johanson, J., and Vahlne, J. (1992) ‘Management of Foreign Market Entry’, Scandinavian International Business Review, Vol.1 No. 3, pp. 9-27.

Kandell, J. (2010) China's Africa Play. Institutional Investor-International Edition, June, Vol. 35 No. 5, pp. 46-50.

Kempe, F. (2006) 'Politics \& Economics - Thinking Global: Africa Emerges as Strategic Battleground; Challenges for U.S. Include Terrorist Ties, Energy Issues, Countering China's Inroads', Wall Street Journal, 25 April, A.8.

Kripalani, M., Rocks, D., Halperin, A., and Lakshman, N. (2008) 'India Plays Catch-Up in Africa’. Business Week, 26 May, Vol. 4085, pp. 55.

Kshetri, N. (2011a) "The Global Financial Crisis: Evidence from China and India" Thunderbird International Business Review, Vol 53 No 2, pp. 247-262.

Kshetri, N. (2011b) "Institutional and Economic Foundation of Entrepreneurship in Africa: An Overview”, Journal of Developmental Entrepreneurship,Vol.16 No. 1, pp. 9-35

Kumar, N. (2008) 'Internationalization of Indian Enterprises: Patterns, Strategies, Ownership Advantages, and Implications’, Asian Economic Policy Review, Vol. 3 No. 2, pp. 242-261.

Kumar, N., Pradipta, K., and Mohapatra, S. C. (2009) Challenges for Indian Multinationals--The Global Future, HBS Press Chapter. Available

at:http://harvardbusinessonline.hbsp.harvard.edu/b02/en/common/item_detail.jhtml;jsessioni d=D5WRHOBIDCOVMAKRGWDR5VQBKE0YIISW?id=6745BC\&_requestid=50809. (Accessed 26 October, 2009).

Lagerkvist, J. (2009a) 'Global Media for Global Citizenship in India and China'. Peace Review, Vol. 21 No.3, pp. 367-375.

Lagerkvist, J. (2009b) 'Chinese eyes on Africa: Authoritarian flexibility versus democratic governance’. Journal of Contemporary African Studies, Vol.27 No. 2, pp. 119-134.

Lawrence, T. B., Hardy, C., and Phillips, N. (2002) 'Institutional effects of interorganizational collaboration: The emergence of proto-institutions', Academy of Management Journal, Vol. 45 No. 1, pp. 281-290.

Lee, P. (2009) China doubles down in Africa. Available at:http://www.atimes.com/atimes/China/KG14Ad02.html. (Accessed 26 October, 2009)

Lee, P. (2010) China has a Congo copper headache, Mar 11, 2010. Available at:http://www.atimes.com/atimes/China_Business/LC11Cb02.html. (Accessed 20 August, 2010).

Leggett, K. (2005) 'Staking a Claim: China Flexes Economic Muscle Throughout Burgeoning Africa; Beijing Forges Deep Alliances With War-Torn Nations, Countering U.S. Influence; A Dam Gets Built on the Nile’, Wall Street Journal, 29 March, A.1.

López-Santana, M. (2006) 'The domestic implications of European soft law: framing and transmitting change in employment policy', Journal of European Public Policy, Vol. 13 No. 4, pp. 481-499.

Macdonald, Nancy, (2010) Beijing's new playing field, Maclean's, 10/4/2010, Vol. 123 No. 38, pp. 32-36

Markey, D. (2009) “Developing India’s Foreign Policy Software", Asia Policy 8 (July 2009).Available at: http://www.nbr.org/publications/element.aspx?id=387. (Accessed 20 August, 2010)

Markusen, J. R., and Venables, A. J. (1999) 'Foreign direct investment as a catalyst for industrial development', European Economic Review, Vol.43 No. 2, pp. 335-356. 
Matthias, S. (2006) 'Special issue: India', New Statesman, January 30, pp. 20 - 39.

MEA. (2009) Republic of Angola, Minister of State for External Affairs, Government of India. Available at: http://meaindia.nic.in/foreignrelation/11fr02.pdf. (Accessed 26 October, 2009).

Michel, S. (2008) 'When China met Africa', Foreign Policy, May/June, pp. 39-46.

Ministry of Foreign Affairs, the People's Republic of China. (2006). Sino-Zimbabwean partnership presents rosy picture. Available at:

http://www.fmprc.gov.cn/zflt/eng/gfbd/t402630.htm. (Accessed 26 October, 2009)

Ministry of Foreign Affairs, the People's Republic of China. (2003) China and Congo. Available at: http://www.mfa.gov.cn/eng/wjb/zzjg/fzs/gjlb/2954/t16482.htm. (Accessed 26 October, 2009)

Nesbitt, F. N. (2009) Clinton Tone-Deaf During Africa Trip. Available at: http://www.fpif.org/fpiftxt/6374. (Accessed 26 October, 2009)

Newbusinessethiopia.com. (2010) China, Ethiopia to Boost Trade to Three Billion USD, 12 January.Available at:

http://www.newbusinessethiopia.com/index.php?option=com_content\&view=article\&id=59: china-ethiopia-to-boost-trade-to-three-billion-usd-\&catid=35:trade\&Itemid=12. (Accessed 20 August, 2010).

Nidumolu, R. et al. (1996) 'Information Technology for Local Administration Support: The Governorates Project in Egypt’, MIS Quarterly, Vol. 20 No. 2, pp.196-224.

Noronha, C. (2007) The future is bright. June. Available at: http://www.tataafrica.com/Mediaroom/articles_and_interview_the_future.htm. (Accessed 20 October, 2009)

North, D. C. (1990) Institutions, Institutional Change and Economic Performance. Cambridge University Press, Cambridge, UK.

N'Sakila, G. M. (2008) 'The Chinese Presence in Lubumbashi, DRC', The China Monitor, 24, Center for Chinese Studies, University of Stellenbosch, 7.

Nye, J. (2004) 'Soft Power: The Means to Success in World Politics'. Public Affairs, New York. nytimes.com. (2010). Sinopec Stakes \$2.5 Billion Upstream Foothold. Available at:http://dealbook.blogs.nytimes.com/2010/03/29/sinopec-stakes-2-5-billion-upstreamfoothold.(Accessed 20 August, 2010).

Omungo, R. (2007) 'Trade-Kenya: Creating Designs for Chinese Traders to Copy’. IPS News. Available at:http://ipsnews.net/news.asp?idnews=38580. (Accessed 26 October, 2009).

Ong, A., and Nonini, D. (1997). Chinese modernities: Narratives of nation and of capitalism. In Underground Empires: The Cultural Politics of Modern Chinese Transformation. Routledge, New York.

pambazuka.org. (2009) India-South Africa trade set to soar to $\$ 12$ billion by 2012. Available at:http://www.pambazuka.org/en/category/africa_china/54617. (Accessed 26 October, 2009).

Pan. (2006). China, Africa, and Oil. Available at: http://www.cfr.org/publication/9557. (Accessed 26 October, 2009).

Pant, H. V. (2008) 'China in Africa: The Push. Continues but All's Not Well', Defense \& Security Analysis, Vol. 24 No. 1, pp.33-43.

Parto, S. (2005) 'Economic Activity and Institutions: Taking Stock', Journal of Economic Issues, Vol. 39 No. 1,pp. 21-52.

Pei, M. (2006) ‘The Dark Side of China's Rise’, Foreign Policy, Vol. 153, pp. 32-40. 
People's Daily Online. (2001). Economic, Trade Cooperation between Angola, China Bodes Promising. Available at:

http://english.peopledaily.com.cn/english/200104/05/eng20010405_66876.html. (Accessed 26 October, 2009).

Peta, B. (2005). Lesotho textile workers left in rags. Available at:http://www.thestar.co.za/index.php?fSectionId=225\&fArticleId=2500450. (Accessed 4 September, 2009).

Pew Research Center. (2009a). Opinion of China. Available at: http://pewglobal.org/database/?indicator=24. (Accessed 4 September, 2009)

Pew Research Center. (2009b). Opinion of the United States. Available at:http://pewglobal.org/database/?indicator=1. (Accessed 4 September, 2009).

Pilling, D. (2010). China at Number Two ... and counting. Available at:http://www.ft.com/cms/s/0/e9d0f552-a963-11df-a6f2-00144feabdc0.html. (Accessed 20 August, 2010).

pretorianews.co.za 2011. India comes to the rescue of Africa. May 25 2011, Available at:http://www.pretorianews.co.za/india-comes-to-the-rescue-of-africa-1.1073776

Ranneberger, M. E. (2005). Statement before The House International Relations Subcommittee on Africa, Global Human Rights, And International Operations. Available at:http://wwwa.house.gov/international_relations/109/ran072805.pdf. (Accessed 4 September, 2007).

Rasiah, R, and Ofreneo, R. E. (2009) 'Introduction: The Dynamics of Textile and Garment Manufacturing in Asia',Journal of Contemporary Asia, Vol. 39 No. 4, pp. 501-511.

Rees, J. A. (1998) ' Regulation And Private Participation In The Water And Sanitation Sector', Natural Resources Forum, Vol. 22, pp. 95-105.

Reuters. (2006). Mauritius to sign trade deals with India, Pak. Available at:http://www.bilaterals.org/article.php3?id_article=5876. (Accessed 26 October, 2009).

Sautman, B. (2001) 'Peking Man and the Politics of Paleoanthropological Nationalism In China', The Journal of Asian Studies, Vol.60 No.1, pp. 95-124.

Schatz, J. J., and Sappenfield, M. (2008) 'On China's heels, India vies for its old edge in Africa', Christian Science Monitor, May 5, Vol.100 No. 112, pp. 1-12.

Scott, D. (2009) 'India's “Extended Neighborhood” Concept: Power Projection for a Rising Power'. India Review, Vol. 8 No.2, pp. 107-143.

Scott, W. R. (1995) Institutions and organizations. Sage, Thousand Oaks, CA.

Shaw, T. M., Cooper, A. F., and Antkiewicz, A. (2007) 'Global and/or regional development at the start of the 21st century? China, India and (South) Africa'. Third World Quarterly, Vol.28 No.7, pp. 1255-1270.

Shinn, D., and Eisenman, J. (2008) Responding to China in Africa. American Foreign Policy Council, Washington, D.C. Available at :www.afpc.org. (Accessed 26 October, 2009)

Srivastava, S. (2008) India loads up presents for African safari. Asia Times Online. Available at:http://www.atimes.com/atimes/South_Asia/JD12Df01.html.(Accessed 26 October, 2009).

Sterling, B. (2009) India and China in Africa. Available at:http://www.wired.com/beyond_the_beyond/2009/08/india-and-china-in-africa/. (Accessed 26 October, 2009)

Suchman, M. C. (1995) 'Managing Legitimacy: Strategic and Institutional Approaches', Academy of Management Review, Vol.20, pp. 571-610. 
Suri, S., and Mahajan-Bansal, N. (2009) 'The Siege of Africa', Available at:http://www.forbes.com/2009/08/24/africa-manubhai-madhvani-forbes-india-china.html. (Accessed 20 August, 2010).

Teece, D., Gary, P., and Amy, S. (1997) 'Dynamic Capabilities and Strategic Management', Strategic Management Journal, Vol.18 No. 7, pp. 509-533.

telegraph.co.uk . (2011) 'China in Africa at a glance', 13 February 2011,Available at:http://www.telegraph.co.uk/news/worldnews/africaandindianocean/zimbabwe/8315107/Ch ina-in-Africa-at-a-glance.html

Teslik, H. (2007) 'India Eyes African Investments', The Council on Foreign Relations. Available at:http://www.cfr.org/publication/13722/india_eyes_african_investments.html?breadcrumb= \%2F. (Accessed 26 October, 2009).

The Economist. (2006) 'Africa's economy: A glimmer of light at last?' 24 June.

Thompson, D. (2005) 'China's Soft Power in Africa: From The "Beijing Consensus” To Health Diplomacy', China Brief, 5, 21. Available at:http://www.jamestown.org/publications_details.php?volume_id=408\&issue_id=3491\&arti cle_id=2370717 or http://www.asiamedia.ucla.edu/article.asp?parentid=32003. (Accessed 26 October, 2009).

Tsai, H. and Eisingerich, A.B. (2010) 'Internationalization Strategies of Emerging Markets Firms.', California Management Review, Vol. 53 No. 1, pp.114-135

UNDP. (2008) Human development Report 2007/2008. Available at:http://hdr.undp.org/en/reports/global/hdr2007-2008/. (Accessed 26 October, 2009).

Upadhyay. (2007) 'Ashoak Africa is big game for China',The Hindu Business Line. Available at:http://www.blonnet.com/2007/01/05/stories/2007010500470800.htm. (Accessed 26 October, 2009).

Van de Walle, N. (2008). Book Reviews: Africa's Silk Road: China and India's New Economic Frontier. Foreign Affair, January/February. Available at:http://www.foreignaffairs.com/articles/63201/nicolas-van-de-walle/africas-silk-road-chinaand-indias-new-economic-frontier. (Accessed 26 October, 2009).

Vines, A., and Oruitemeka, B. (2008) 'India's Engagement with the African Indian Ocean Rim, States', Africa Programme Paper: AFP P 1/08, Chatham House, 4 April. Available at:http://www.chathamhouse.org.uk/files/11293_india_africa0408.pdf. (Accessed 26 October, 2009).

Wilson, E. J. (1990) 'Strategies of State Control of the Economy: Nationalization and Indigenization in Black Africa', Comparative Politics, Vol. 22 No.4, pp. 401-419.

Xinhua News Agency. (2006) 'China, Uganda Join Hands in Promoting Bilateral Ties', Available at:http://www.china.org.cn/english/features/wenjiabaoafrica/172550.htm. (Accessed October 26, 2009).

Xinhua. (2009a) 'China-Africa trade up 45\% in 2008 to \$107 billion', Available at:http://www.chinadaily.com.cn/china/2009-02/11/content_7467460.htm. (Accessed 26 October, 2009).

Xinhua. (2009b) China Calls for Developing Nations' Greater Presence in UNSC. Available at: www.china.org.cn/. (Accessed 26 October, 2009).

Yin, E. and Choi, C.J. (2005)'The Globalization Myth: The Case of China’, Management International Review, Vol.45, pp.103-120. 
Zafar, A.( 2007). 'The Growing Relationship Between China and Sub-Saharan Africa:

Macroeconomic, Trade, Investment, and Aid Links,' World Bank Research Observer, Vol. 22 No.1, pp. 103-130.

Zahra, S., and George, G. (2002) 'Absorptive Capacity: A Review, Reconceptualization, and Extension’, The Academy of Management Review, Vol.27 No. 2, pp.185-203.

Zhan, S. (2006) 'Dangqian zhongfeiguanxi mingan wenti' yantaohui zhaokai,' (Conferencec onvened on 'sensitive issues' in contemporary Sino-African relations). Xiya yu feizhou (West Asia and Africa), no. 9: pp.67_8.

Zim Online. (2005) 'Mugabe to crack down on internet use;. Available at:http://www.zimbabwesituation.com/jun10_2005.html\#link10. (Accessed 20 October, 2007).

Zucker, L. G. (1988). 'Where Do Institutional Patterns Come From? Organizations as Actors in Social Systems’, In Zucker, L.G. (eds.). Institutional Patterns and Organizations: Culture and Environment. Ballinger, Cambridge, MA, p.26. 
Table 1: A Comparison of China's and India's Trade in selected African countries

\begin{tabular}{|c|c|c|c|c|c|c|c|}
\hline Country & $\begin{array}{l}\text { Population } \\
\left({ }^{\prime} 000\right)^{\mathrm{v}}\end{array}$ & $\begin{array}{c}\text { GDP per } \\
\text { capita } \\
\text { (PPP } \\
\text { US\$) }\end{array}$ & $\begin{array}{l}\text { Commonw } \\
\text { ealth } \\
\text { member? }^{\mathrm{c}}\end{array}$ & $\begin{array}{c}\text { Political } \\
\text { Rights } \\
\text { Score(PR) } \\
\text { Civil } \\
\text { Liberties } \\
\text { Score } \\
\text { (CL)l }\end{array}$ & $\begin{array}{l}\text { India’s trade } \\
\text { (US\$, million) }\end{array}$ & $\begin{array}{l}\text { China's } \\
\text { trade (US\$, } \\
\text { million) }\end{array}$ & $\begin{array}{c}\text { ICRG } \\
\text { Composite } \\
\text { Risk Rating } \\
\text { (rank out of } \\
140 \\
\text { countries) } \\
\text { (Jan. 2010) }\end{array}$ \\
\hline Angola & $17,499.4$ & 2,335 & No & $\begin{array}{l}\text { PR: } 6 \\
\text { CL: } 5\end{array}$ & $\begin{array}{l}\text { 2004: 74; 2005: } \\
\text { 155, 2006:446; } \\
\text { 2007: 1,281 }\end{array}$ & $\begin{array}{l}\text { 1998: } 190 \\
\text { 1999: } 372 \\
\text { 2000: } 1,876^{\text {u }}\end{array}$ & \\
\hline Congo & $3,847.2$ & 1,262 & No & $\begin{array}{l}\text { P R: } 6 \\
\text { CL: } 5\end{array}$ & 2004: $106^{\mathrm{q}}$ & $\begin{array}{l}2005: 2,050^{\mathrm{s}} \\
2002: 291^{\mathrm{r}}\end{array}$ & $72.3(49)$ \\
\hline DRC & $64,703.6$ & 714 & No & $\begin{array}{l}\text { PR: } 5 \\
\text { CL: } 6\end{array}$ & $\begin{array}{l}\text { 2000: } 4.73 \text {; } \\
\text { 2001: } 3.75 \text {, } \\
\text { 2002: 4.31, } \\
\text { 2003: 11.24, } \\
\text { 2004: 5.36, } \\
\text { 2005: } 16.24, \\
\text { 2006: } 18.24, \\
\text { 2007: } 1382.19\end{array}$ & 2002: 31 & 44 (139) \\
\hline Kenya & $38,549.7$ & 1,240 & Yes & $\begin{array}{l}\text { PR: } 4 \\
\text { CL: } 3\end{array}$ & 2004-05: $450^{j}$ & 2005: 475f & 61.3 (111) \\
\hline Mauritius & $1,271.5$ & 12,715 & Yes & $\begin{array}{l}\text { PR: } 1 \\
\text { CL: } 2\end{array}$ & $\begin{array}{l}\text { 2004: } 245 \\
\text { 2005-06: } 207 \\
\text { 2006-07: } 751^{\circ}\end{array}$ & $2008: 323^{\mathrm{P}}$ & \\
\hline Nigeria & 151,478 & 1,128 & Yes & $\begin{array}{l}\text { PR: } 4 \\
\text { CL: } 4\end{array}$ & $\begin{array}{l}\text { 2008: } 13,000 \\
2007: 8,000^{m}\end{array}$ & $\begin{array}{l}\text { 2007: 4,300 } \\
\text { 2009: } \\
\$ 6373^{\mathrm{w}}\end{array}$ & 60.8 (112) \\
\hline South Africa & $48,832.1$ & 11,110 & Yes & $\begin{array}{l}\text { PR: } 2 \\
\text { CL: } 2\end{array}$ & $\begin{array}{l}\text { 1993: } 45 \\
\text { 2007-08: } 6,000^{i}\end{array}$ & $\begin{array}{l}\text { 2003: 3,870 } \\
\text { h } \\
\text { 2006: } 8,800\end{array}$ & $70(61)$ \\
\hline Sudan & $\begin{array}{l}39,445.0 \\
\end{array}$ & 2,083 & No & $\begin{array}{l}\text { PR: } 7 \\
\text { CL: } 7\end{array}$ & $\begin{array}{l}\text { 1998: 90; 1999: } \\
\text { 69 } \\
\text { 2000: 83; } \\
\text { 2001: 97 } \\
\text { 2002: 111; } \\
\text { 2003: 149; } \\
\text { 2004: 225; } \\
\text { 2005: 349 } \\
\text { 2006: 624; } \\
\text { 2007: 563 } \\
\text { 2008: 1,122 } \\
\end{array}$ & $\begin{array}{l}2006: \\
2,900^{\mathrm{g}}\end{array}$ & $53.3(133)$ \\
\hline Uganda & $31,902.6$ & 1,454 & Yes & $\begin{array}{l}\text { PR: } 5 \\
\text { CL: } 4\end{array}$ & $\begin{array}{l}\text { 1984: } 6 \\
\text { 2003: } 106 \text { e }\end{array}$ & 2005: $100^{t}$ & $64.3(98)$ \\
\hline Zimbabwe & $13,481.2$ & 2,038 & No & $\begin{array}{l}\text { PR: } 7 \\
\text { CL: } 6\end{array}$ & 2006: $40^{c}$ & 2005: $280^{\mathrm{d}}$ & 48.3 (138) \\
\hline
\end{tabular}


${ }^{\mathrm{a}}$ MEA (2009); ${ }^{\mathrm{b}}$ Embassy of India, Khartoum (2009); ${ }^{\mathrm{c}}$ globalinsight.com (2008); ${ }^{\mathrm{d}}$ Ministry of Foreign Affairs, the People's Republic of China (2006); ${ }^{\mathrm{e} F I C C I}$ (2004); ${ }^{\mathrm{f}}$ Omungo (2007); ${ }^{\mathrm{g}}$ Foxnews.com (2007); ${ }^{\mathrm{h}}$ fmprc.gov.cn (2004); 6000 ${ }^{\mathrm{i}}$ pambazuka.org (2009); ${ }^{\mathrm{j}}$ Vines and Oruitemeka (2008); ${ }^{\mathrm{k}} \mathrm{UNDP}$ (2008); ${ }^{\mathrm{l}}$ a higher score represents lower freedom ( Freedom House 2008); 'business-standard.com (2009); ${ }^{\mathrm{n}}$ financialnigeria.com (2008); ${ }^{\circ}$ Reuters (2006); ${ }^{\mathrm{p}}$ chinadaily.com (2009); ${ }^{\mathrm{q}}$ Department of Commerce (2005); ${ }^{\mathrm{r}}$ Ministry of Foreign Affairs, the People's Republic of China (2003); ${ }^{\mathrm{s} C h i n a ~ E c o n o m i c ~ R e v i e w ~(2006) ; ~}{ }^{\mathrm{t}}$ Xinhua News Agency (2006); ${ }^{\mathrm{u} P e o p l e ' s ~ D a i l y ~}$ Online (2001); ${ }^{v}$ Euromonitor International from national statistics/UN. ${ }^{\mathrm{w}}$ afriqueavenir.org/en (2010).

\section{Table 2: Chinese and Indian trade and investment links with SSA: A comparison in selected dimensions}

\begin{tabular}{|c|c|c|}
\hline & China & India \\
\hline $\begin{array}{l}\text { Trade in manufactured } \\
\text { goods/commodities }^{f}\end{array}$ & $\begin{array}{l}\text { - Mostly buys raw materials } \\
\text { from Africa and sends finished } \\
\text { goods such as clothing, electronics } \\
\text { and tools back to the continent }{ }^{\mathrm{d}} \text {. } \\
\text { - Imports of commodities such } \\
\text { as cotton and food products, which } \\
\text { undergo labor-intensive } \\
\text { processing in Africa are } \\
\text { increasing. }\end{array}$ & $\begin{array}{l}\text { Like China, it exports } \\
\text { significantly more manufactured } \\
\text { goods, machinery, electronics, } \\
\text { and medical supplies to Africa } \\
\text { than its imports from Africa. }\end{array}$ \\
\hline $\begin{array}{l}\text { Magnitude \& } \\
\text { composition of } \\
\text { investment nature of } \\
\text { ownership \& control } \\
\text { (subsidiary/ branch, joint }^{\text {ventures, strategic }} \\
\text { alliances forged etc.) }^{\text {a }}\end{array}$ & $\begin{array}{l}\text { - The average firm operating in } \\
\text { the region is a large SOE with a } \\
\text { high degree of vertical integration } \\
\text { - Most sales are to government } \\
\text { entities, thanks to their ability to } \\
\text { out-compete other bidders. } \\
\text { - Joint ventures with local firms } \\
\text { increasing mainly to export from } \\
\text { Africa to other markets. }\end{array}$ & $\begin{array}{l}\text { - The average firm operating in the } \\
\text { region is in the private sector with } \\
\text { diverse sizes } \\
\text { - They enter by acquiring } \\
\text { established businesses } \\
\text { - The degree of vertical integration } \\
\text { lower than Chinese counterparts } \\
\text { - Large sales with private entities. } \\
\text { - Joint ventures with local firms } \\
\text { increasing mainly to export from } \\
\text { Africa to other markets. }\end{array}$ \\
\hline $\begin{array}{l}\text { Sectors / industries of loci } \\
\text { of investment }^{\mathrm{f}}\end{array}$ & $\begin{array}{l}\text { - Diverse sectors mostly large } \\
\text { infrastructure projects. }\end{array}$ & $\begin{array}{l}\text { - Mainly in telecommunications, } \\
\text { pharmaceuticals and manufacturing b }\end{array}$ \\
\hline $\begin{array}{l}\text { Partnerships and } \\
\text { integration with local } \\
\text { communities }^{\text {a,f }}\end{array}$ & $\begin{array}{l}\text { - Lower degree of integration of } \\
\text { managers and workers into the } \\
\text { local social, economic, cultural } \\
\text { and political lives in Africa } \\
\text { - Provides some training to } \\
\text { Africans. }\end{array}$ & $\begin{array}{l}\text { - Managers and workers are } \\
\text { facilitated and encouraged participate } \\
\text { in political, economic and cultural } \\
\text { activities } \\
\text { - The presence of informal ethnic } \\
\text { networks further stimulates the } \\
\text { participation. }\end{array}$ \\
\hline $\begin{array}{l}\text { Impact on capability } \\
\text { building } \& \text { value added } \\
\text { activities }^{\mathrm{ce}}\end{array}$ & - Limited. & - Limited. \\
\hline $\begin{array}{l}\text { Strategic / commercial } \\
\text { objectives involved in } \\
\text { commodity trade }\end{array}$ & $\begin{array}{l}\text { - Responding to the rapid energy } \\
\text { demand growth }\end{array}$ & $\begin{array}{l}\text { - Private companies' profits from } \\
\text { commodity trades }\end{array}$ \\
\hline
\end{tabular}

${ }^{\mathrm{a}}$ Broadman (2011); ${ }^{\mathrm{b}}$ pretorianews.co.za (2011); ${ }^{\mathrm{c}}$ Broadman (2007); ${ }^{\mathrm{d}}$ Baldauf (2010); ${ }^{\mathrm{e}}$ Kshetri (2011b); ${ }^{\mathrm{f}}$ Broadman (2008); ${ }^{\mathrm{f}}$ Baldauf (2011).

Table 3: A comparison of some international trade related indicators in China and India 


\begin{tabular}{|l|l|l|}
\hline Indicator & China & India \\
\hline Per capita GDP, US\$ 2005 & 1,713 & 736 \\
\hline Total population (millions & $1,313.0$ & $1,134.4$ \\
\hline $\begin{array}{l}\text { Research and development } \\
\text { (R\&D) expenditures } \\
\text { (\% of GDP) (2000-2005) }^{\mathrm{c}}\end{array}$ & 1.4 & 0.8 \\
\hline Researchers in R\&D (per million people) (1990-2005) $^{\mathrm{c}}$ & 708 & 119 \\
\hline Patents granted to Residents (per million People) (2000-2005) ${ }^{\mathrm{c}}$ & 16 & 1 \\
\hline Receipts of royalties and license fees (US\$ per person) 2005 $^{\mathrm{c}}$ & 0.1 & -- \\
\hline No. of companies in the Forbes' “Global 2000” list $^{\mathrm{b}}$ & 91 & 47 \\
\hline $\begin{array}{l}\text { Electricity consumption } \\
\text { per capita, 2004 (\% change, 1990-2004) }\end{array}$ & $1,684(212.4)^{\mathrm{a}}$. & $618(77.6)^{\mathrm{a}}$. \\
\hline $\begin{array}{l}\text { GDP per unit of energy use, 2004 (2000 PPP US\$ per } \\
\text { kg of oil equivalent) (\% change, 1990-2004) }\end{array}$ & $4.4(108.6)^{\mathrm{a}}$. & $5.5(37.1)^{\mathrm{a}}$. \\
\hline
\end{tabular}

${ }^{\mathrm{a}}$ UNDP (2008); ${ }^{\mathrm{b}}$ DeCarlo (2009); ${ }^{\mathrm{C}} \mathrm{UNDP}$. (2008)

\section{Notes:}

